\title{
PLACENTAL ALDOSE REDUCTASE ACTIVITY AND FOETAL BLOOD FRUCTOSE DURING BOVINE PREGNANCY
}

\author{
TORE HÅSTEIN AND WEIERT VELLE
}

\author{
Department of Physiology, \\ The Veterinary College of Norway, Oslo \\ (Received 26th October 1966, revised 6th February 1967)
}

\begin{abstract}
Summary. Bovine placental aldose reductase has been partially purified from foetal cotyledons and the levels of activity measured in forty samples from foetuses 1 to 9 months old. A statistically significant increase in the specific activity of the enzyme with advancing pregnancy was observed.

No significant correlation was found between aldose reductase activity and foetal blood fructose levels.

The increase in enzyme activity during pregnancy followed a pattern similar to that previously observed for urinary oestrogens in cows.
\end{abstract}

\section{INTRODUCTION}

In many mammalian species, fructose is the only free hexose of seminal plasma (Mann, 1964). This carbohydrate is also a major component of the free hexose in the foetal blood of the cow and certain other species (Goodwin, 1956).

The formation of free fructose has been studied by Hers who has shown that, in sheep, fructose formation in the seminal vesicles takes place in a two-step reaction involving the reduction of free glucose to sorbitol by the NADP-dependent enzyme aldose reductase (alditol: NADP oxidoreductase, E.C.1.1.1.21), and the oxidation of sorbitol to fructose by the NAD-dependent enzyme 1-iditol dehydrogenase (L-iditol: NAD oxidoreductase, E.C.1.1.1.14), both enzymes being present in the same tissue (Hers, 1960).

The situation regarding the origin of free fructose in the foetus is different in so far as the two reactions mentioned seem to take place in separate tissues. According to Hers $(1957,1960)$ placental tissue catalyses the conversion of glucose to sorbitol, while the foetal liver contains the enzyme responsible for the oxidation of sorbitol to fructose.

The soluble placental NADP-dependent aldose reductase from bovine tissue has been partially purified and characterized by Velle \& Engel (1964) who showed that not only glucose, but also other aldehydes, for example lactaldehyde and glyceraldehyde, can serve as substrates for the enzyme.

The purpose of the present investigation has been to measure aldose reductase activity during advancing pregnancy and to look for possible relationships between the observed values and the free fructose levels of foetal blood. 


\section{MATERIALS AND METHODS}

Tissue

Uteri from healthy, pregnant cows were obtained at the local abattoir. Uteri were removed immediately upon slaughter and brought to the laboratory where tissues were prepared as soon as possible. Homogenization never took place later than $2 \mathrm{hr}$ after the animals were killed. Control measurements showed that there was no significant loss in enzyme activity during a period of $2 \mathrm{hr}$ at room temperature. Samples from forty animals with foetuses 1 to 9 months old were collected. The foetal age was calculated according to the formula $L=X(X+2)$, where $X$ is the age in months, and $L$ is the crown-rump length of the foetus in centimetres (Baier \& Schaetz, 1958).

The placental tissue used for enzyme assays was cotyledons from which as much connective tissue as possible had been removed. The cotyledons have previously been shown to contain the highest levels of enzyme activity (Velle \& Engel, 1964). Blood samples for fructose determination were taken from vessels within the foetal liver.

\section{Reagents}

NADPH was obtained from Boehring und Soehne, Mannheim. D-L-Glyceraldehyde was obtained from Fluka, Basel. The glyceraldehyde solutions were kept in the frozen state, de-dimerized just before use on a water bath at $85^{\circ} \mathrm{G}$ for $5 \mathrm{~min}$, and then kept at $37^{\circ} \mathrm{C}$ during the periods of assay.

\section{Preparation of the enzyme}

The cotyledons were cut into small pieces and, whenever possible, $30 \mathrm{~g}$ of tissue was added to $60 \mathrm{ml}$ of homogenizing solution $(1 \mathrm{~mm}$ cysteine hydrochloride, $1 \mathrm{~mm}$ disodium EDTA, $10 \mathrm{~mm}$ nicotinamide, $30 \mathrm{~mm}$ sodium bicarbonate). When the foetal age was less than 3 months, smaller quantities of tissue were obtained. All operations were carried out near $0^{\circ} \mathrm{C}$.

The tissue samples were homogenized for $2 \mathrm{~min}$ at maximal speed in an AtoMix blendor. The homogenate was centrifuged at $4000 \mathrm{~g}$ for $20 \mathrm{~min}$, the supernatant fluid was collected quantitatively and $1 / 10$ th of the volume of $0.1 \mathrm{M}$ calcium chloride was added in order to precipitate microsomes. After stirring in the cold for $1 \mathrm{hr}$, the solution was centrifuged at 15,000 $\mathrm{g}$ for $30 \mathrm{~min}$. The supernatant fluid $(0.1 \mathrm{ml})$ was then assayed for protein and enzyme activity.

\section{Protein determinations}

All samples were assayed for protein by two methods; by the micro-Kjeldahl method, and by spectrophotometry at $280 \mathrm{~m} \mu$, using quartz cuvettes with a $\mathrm{I} \mathrm{cm}$ light path. There was a good correlation between the two methods, the average difference being only $5.9 \%$ in the concentration range 4 to $16 \mathrm{mg}$ protein $/ \mathrm{ml}$, spectrophotometry giving the highest values. Specific activities were calculated on the basis of the micro-Kjeldahl values.

\section{Enzyme assay}

Enzyme activity was measured in a system of $0.1 \mathrm{M}$ tris- $\mathrm{HCl}, \mathrm{pH} 7.5,167$ $\mathrm{mm}$ glyceraldehyde and $0.167 \mathrm{~mm} \mathrm{NADPH}$ in a final volume of $3.0 \mathrm{ml}$. 
The rate of oxidation of NADPH was followed at $340 \mathrm{~m} \mu$ in a Zeiss N4QIII spectrophotometer using glass cuvettes of $1 \mathrm{~cm}$ light path. Glyceraldehyde was chosen as substrate because of its high reaction rate compared with that of glucose (Velle \& Engel, 1964). The reaction was initiated with substrate. Readings were made at $10-\mathrm{sec}$ intervals, starting $20 \mathrm{sec}$ after the addition of substrate, and initial rates were used in the calculations.

One unit of enzyme activity is given as the amount of protein catalysing the transformation of $1 \mu$ mole of substrate/minute at $37^{\circ} \mathrm{C}$ under the conditions specified above. Specific activity is given as units $/ \mathrm{mg}$ protein. Free fructose in blood was determined by the resorcinol method (Bacon \& Bell, 1948).

Enzyme activity and foetal age

\section{RESULTS}

In Text-fig. 1 the aldose reductase level of placental tissue is shown as a

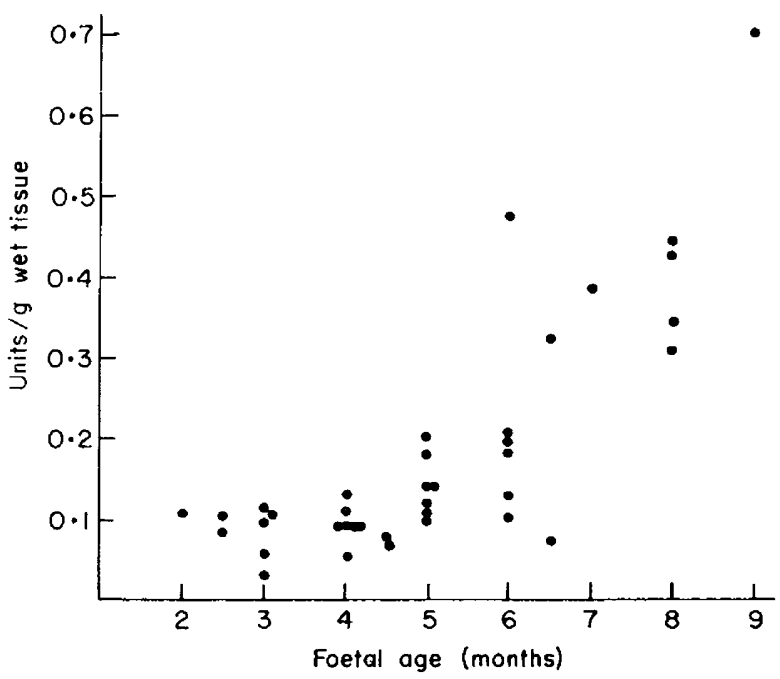

TEXT-FIG. 1. Aldose reductase levels/g of wet tissue as a function of foctal age.

function of foetal age. An increase in activity per unit weight of wet tissue during the last part of gestation is clearly indicated. Text-fig. 2 shows the relationship between the specific activity of the enzyme and the calculated foetal age. One sample from a 1-month-old foetus was analysed, but enzyme activity could not be detected.

There was a highly significant correlation between the crown-rump length of the foetuses and the specific activity of the placental aldose reductase, the coefficient of regression being $0.59(P<0.001)$. The observations were also split into three foetal age groups, as follows: Group 1, 2 to 4.5 months; Group 2, 5 to 6.5 months and Group 3, 7 to 9 months.

By analysis of variance (Table 1) significant differences in the levels of specific enzyme activity between Groups 1 and $2(P<0.05)$ and between Groups 2 and 3 $(P<0.05)$ were found. 
Enzyme activity and foetal blood fructose

Foetal blood fructose was determined in twenty-six out of the forty cases examined. No significant correlation was found $(P>0 \cdot 2)$.

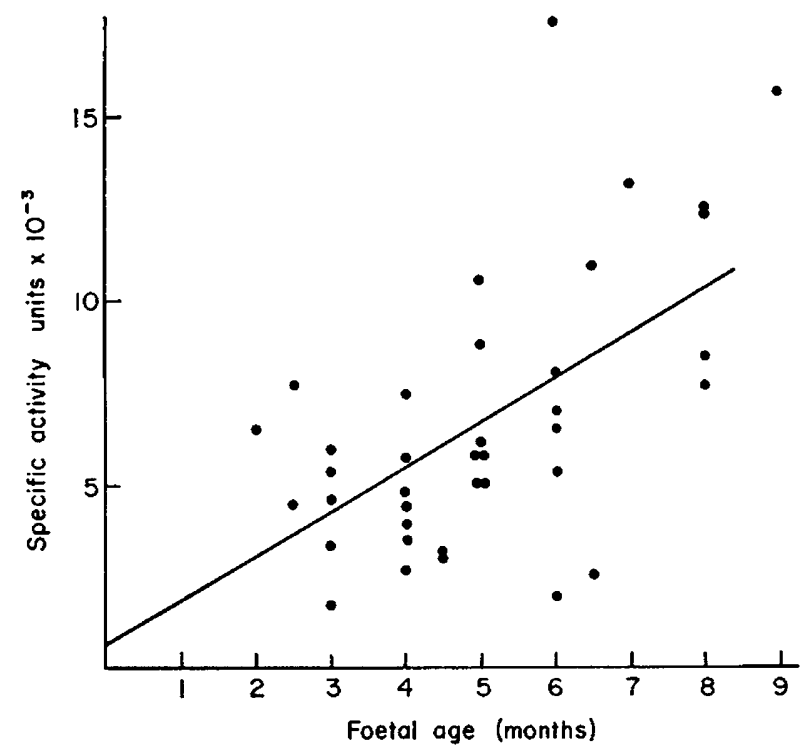

TeXT-FIc. 2. Specific activity of aldose reductase as a function of foetal age.

Enzyme activity and foetal sex

When the specific activities of placental aldose reductase of female and male foetuses were compared, no significant difference was observed (analysis of variance, $P>0 \cdot 2$ ).

TABLE 1

PLACENTAL ALDOSE REDUGTASE AGTIVITY AND FOETAL AGE

Summary of the analysis of variance

\begin{tabular}{|c|c|c|c|}
\hline Foetal age $\dagger$ & $\begin{array}{l}\text { Source of } \\
\text { variation }\end{array}$ & d.f. & $\begin{array}{l}\text { Variance } \\
\text { ratio }\end{array}$ \\
\hline Groups 1 and 2 & $\begin{array}{l}\text { Between groups } \\
\text { Within groups }\end{array}$ & $\begin{array}{r}1 \\
30\end{array}$ & $6 \cdot 24^{*}$ \\
\hline Groups 1 and 3 & $\begin{array}{l}\text { Between groups } \\
\text { Within groups }\end{array}$ & $\begin{array}{r}1 \\
21\end{array}$ & $50 \cdot 64 * * *$ \\
\hline Groups 2 and 3 & $\begin{array}{l}\text { Between groups } \\
\text { Within groups }\end{array}$ & $\begin{array}{r}1 \\
19\end{array}$ & $6 \cdot 59 *$ \\
\hline Groups $1: 2: 3$ & $\begin{array}{l}\text { Between groups } \\
\text { Within groups }\end{array}$ & $\begin{array}{r}2 \\
35\end{array}$ & $20 \cdot 34 * * *$ \\
\hline
\end{tabular}

$* P<0.05, * * * P<0.001$.

† Group 1, 2 to 4.5 months; Group 2, 5 to 6.5 months; Group 3, 7 to 9 months.

\section{DISGUSSION}

From Text-fig. 1 it is evident that aldose reductase activity in placental tissue increases with advancing pregnancy. This observation might be explained on the 
basis of a progressive decrease in the water content of the tissue. Since protein determinations were carried out on all samples, a calculation of the specific activity of the isolated fraction was possible. As shown in Text-fig. 2, there is also an increase in aldose reductase activity relative to the total protein present in the fraction isolated. The statistical calculations showed a high degree of positive correlation between the foetal age and specific enzyme activity.

Since the aldose reductase catalyses the first step in the conversion of glucose to fructose, a similar positive correlation might be expected to exist between specific activity and foetal blood fructose. This was not observed. There may be

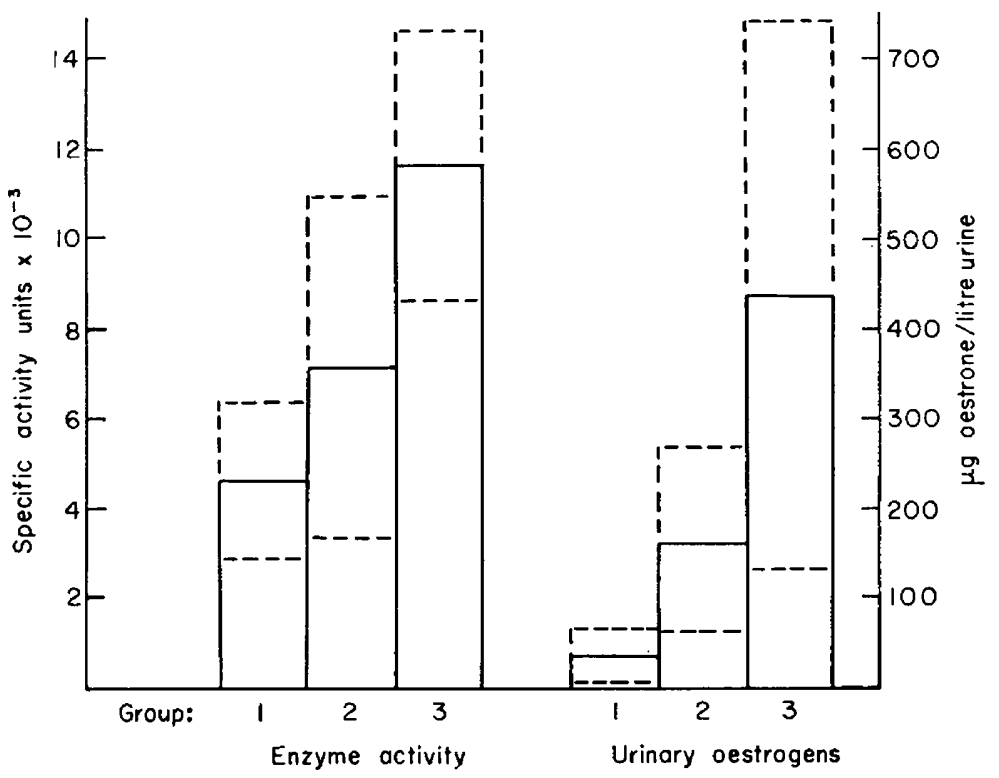

TEXT-FIG. 3. A comparison between the increases in placental aldose reductase activity (present investigation) and in urinary oestrone concentrations during pregnancy in cows (Velle, 1958).

No. of observations

Groups 1: Foetal age: 2 to 4.5 months. Enzyme 17 Oestrone 23

Groups 2: Foetal age: 5 to 6.5 months. Enzyme 15 Oestrone 13

Groups 3: Foetal age: 7 to 9 months. Enzyme 6 Oestrone 16

Dotted lines represent \pm one standard deviation.

several explanations for this finding, one being that some of the free fructose formed in the foetus may be transferred to the maternal circulation. This has recently been shown to take place in goats (Nixon, 1963).

It is interesting to speculate on possible regulatory factors responsible for the gradual increase in aldose reductase activity. In the male animal it has been conclusively shown that the activity of the aldose reductase as well as the ketose reductase is strictly androgen-dependent. Castration caused a rapid decrease in enzyme activity and fructose content in the seminal vesicles and testosterone injections gave rise to normal levels (Samuels, Harding \& Mann, 1962).

As regards the placenta, a similar experimental approach is impossible because, in this case, hormone secretion and enzyme formation take place in the same organ. It is, however, interesting to compare the changes in enzyme levels C.BE. 
with changes in hormone secretion during pregnancy. Using chemical methods, Velle (1958) showed a progressive increase in urinary oestrone excretion to take place during pregnancy in cows. When his material is split into the same foetal age groups as those used for comparing enzyme activities (Table 1), statistical analysis gave significant differences in urinary oestrone concentrations between Groups 1 and $2(P<0.001)$ and between Groups 2 and $3(P<0.01)$. When urinary oestrone concentrations and placental enzyme activity are plotted as in Text-fig. 3, similar patterns of increment with advancing foetal age are found for the two sets of observations.

A possible causative relationship between these two parameters of placental function cannot be entirely ruled out. In this connection, attention is drawn to the very recent observations of Thomas \& Knych (1966) on the effect of oestrogens on fructose formation in the seminal vesicles of castrate mice. These authors found that various oestrogens, when given simultaneously with testosterone, enhanced fructose concentrations in this gland.

\section{ACKNOWLEDGMENTS}

This investigation was partially supported by a P.H.S. research grant, R05 TW00072, from the United States Public Health Service, and by a grant from the Norwegian Research Council for Science and the Humanities.

\section{REFERENCES}

Bacon, J. S. D. \& BeLl, D. J. (1948) Fructose and glucose in the blood of the foetal sheep. Biochem. F. $42,397$.

Baier, W. \& Schaetz, F. (1958) Tierärztliche Geburtskunde, 3rd edn, p. 14. Ferdinand Enke, Stuttgart.

Goodwin, R. F. W. (1956) Division of the common mammals into two groups according to the concentration of fructose in the blood of the foetus. F. Physiol. 132, 146.

Hers, H. G. (1957) Presence of sorbitol in seminal vesicles and in foetal blood of the sheep. Biochem. $\mathcal{F}$. $66,30 \mathrm{p}$.

Hers, H. G. (1960) Le mécanisme de la formation du fructose séminal et du fructose foetal. Biochim. biophys. Acta, 37, 127.

Nixon, D. A. (1963) The transplacental passage of fructose, urea and mesoinositol in the direction from foetus to mother, as demonstrated by perfusion studies in the sheep. F. Physiol. 166, 351.

Mann, T. (1964) The biochemistry of semen and of the male reproductive tract, p. 237. Methuen, London.

Samuels, L. T., Harding, B. W. \& Mann, T. (1962) Aldose reductase and ketose reductase in male accessory organs of reproduction. Distribution and relation to seminal fructose. Biochem. $\mathbf{F} . \mathbf{8 4}$, 39.

Thomas, J. A. \& KNYch E. T., JR. (1966) Further studies on the influence of oestrogens on androgen dependent fructose formation in sex accessory organs. Acta endocr., Copenh. 53, 455.

VELLE, W. (1958) Undersokelser over naturlig forekommende astrogener hos drovtyggere og gris (Investigation on naturally occurring oestrogens in ruminants and the pig), p. 92. Thesis, Veterinary College of Norway, Oslo.

Velle, W. \& Engel, L. L. (1964) Enzymes from bovine placenta and seminal vesicle that oxidize D(-)-1.2-propanediol and other polyols: Their possible relation to fructose formation. Endocrinology, 74, 429 . 